\title{
Implementasi Kebijakan Penataan Ruang Berbasis Mitigasi Bencana Sebagai Upaya Pengurangan Resiko Bencana di Kota Padang
}

\author{
${ }^{1}$ Roni Ekha Putera, ${ }^{2}$ Tengku Rika Valentina, ${ }^{3}$ Siti Annisa Silvia Rosa \\ ${ }^{12}$ Fakultas Ilmu Sosial dan Ilmu Politik, Universitas Andalas, Padang, Indonesia 25163 \\ ${ }^{3}$ Lembaga Ilmu Pengetahuan Indonesia (LIPI), Bandung, Indonesia 40135
}

E-mail: ${ }^{1}$ roniekhaputera@soc.unand.ac.id ; ${ }^{2}$ tengkurika@soc.unand.ac.id ; ${ }^{3}$ sitiannisasr@gmail.com Received: 15 September 2020; Revised: 26 Oktober 2020; Accepted: 28 Desember 2020

\begin{abstract}
The issue of spatial planning becomes crucial for vulnerable areas. Padang, as one of the areas prone to earthquakes, needs to pay attention to the allocation of space. After the 2009 earthquake, it was recorded that Padang City had revised the Regional Spatial Plan (RTRW) twice, namely in 2010 and 2015. In the revised RTRW, mapping of the areas prone to earthquake and tsunami disaster. The purpose of this research is to explain the policy efforts made by the City of Padang in spatial planning based on disaster mitigation. This study used qualitative research methods. The technique of selecting informants using purposive sampling, primary data obtained from interviews, while secondary data from documentation and literature studies. Data analysis was performed using an interactive model. The results showed that the spatial planning in the city of Padang based on Regulation No. 4 of 2012 had paid attention to disaster-prone areas, it can be seen from the categorization of disaster-prone regions in the city of Padang. But there are still disaster-prone areas that even violate the rules of development. For this reason, Padang City Government needs to pay attention to building permit recommendations, especially in disaster-prone areas from the relevant agencies.
\end{abstract}

Keywords:Policy Implementation; Spatial Planning; Disaster Mitigation

\begin{abstract}
Abstrak
Persoalan penataan ruang menjadi hal yang krusial bagi daerah yang rawan bencana. Padang sebagai salah satu daerah yang rawan terhadap bencana gempa bumi perlu memperhatikan peruntukan ruang. Setelah kejadian gempa tahun 2009, tercatat Kota Padang telah dua kali melakukan revisi terhadap Rencana Tata Tuang Wilayah (RTRW) yaitu tahun 2010 dan 2015. Dalam revisi RTRW tersebut telah dilakukan pemetaan terhadap daerah-daerah yang rawan bencana gempa dan tsunami. Tujuan dari Penelitian ini adalah untuk menjelaskan upaya-upaya kebijakan yang dilakukan oleh Kota Padang dalam penataan ruang yang berbasis mitigasi bencana. Penelitian ini menggunakan metode penelitian kualitatif. Teknik pemilihan informan dengan menggunakan purposive sampling, data primer diperoleh dari wawancara, sedangkan data sekunder dari dokumentasi dan studi pustaka. Analis data dilakukan dengan model interaktif. Hasil penelitian menunjukkan bahwa penataan ruang di Kota Padang yang didasarkan pada perda No. 4 Tahun 2012 telah memperhatikan daerah rawan bencana, terlihat dari adanya pengkategorian daerah rawan bencana di Kota Padang. Namun masih terdapat daerah rawan bencana yang masih menyalahi aturan pembangunan. Untuk itu, pemerintah Kota padang perlu memperhatikan rekomendasi izin mendirikan bangunan terutama di daerah-daerah yang rawan bencana dari instansi-instansi yang terkait.
\end{abstract}

Kata Kunci: Implementasi Kebijakan; Penataan ruang; Mitigasi bencana

Link DOI : http://dx.doi.org/10.31314/pjia.9.2.155-167.2020 


\section{PENDAHULUAN}

Persoalan kebencanaan beberapa tahun terakhir ini telah menjadi kajian yang menarik untuk dibahas, tidak saja oleh pemerintah tetapi juga organisasi non pemerintah maupun masyarakat. Berbagai kejadian bencana yang tidak terduga telah membukakan mata semua pihak betapa pentingnya penanggulangan terhadap bencana di masa yang akan datang, bahkan Hughes (Hughes, 2012) dalam bukunya Management and Public Administration mengemukakan bahwa crisis / Disaster Management (manajemen bencana) merupakan salah satu dari isu penting dalam kajian Administrasi Publik. Untuk itu fenomena kebencanaan dapat dilihat dari berbagai perspektif keilmuan, tidak terkecuali Administrasi Publik.

Sebagian masyarakat percaya bahwa bencana yang terjadi merupakan kejadian yang disebabkan oleh aktivitas alam yang merugikan manusia, sementara masyarakat yang lain percaya bahwa bencana adalah merupakan takdir yang maha kuasa sebagai salah satu bentuk hukuman atau peringatan bagi umat manusia. Seperti yang diungkapkan oleh Shaluf (Shaluf, 2007) bahwa kejadian bencana di muka bumi ini terjadi baik itu karena kehendak tuhan atau act of god ataupun bencana hasil perbuatan manusia. Namun terlepas dari keyakinan tersebut Badan Nasional Penanggulangan Bencana menyebutkan bahwa $85 \%$ bencana yang terjadi selama lima tahun terakhir ini terjadi sebagai akibat dari kerusakan lingkungan hidup dan sekitar $80 \%$ penduduk Indonesia tinggal di daerah rawan bencana (BNPB, 2014). Ibaratnya, Indonesia adalah laboratorium bencana di mana setiap orang belajar tentang berbagai jenis bencana dan akibat yang mengikutinya seperti Gempa Bumi dan Tsunami (Pramusinto, 2009).
Dengan tingginya tingkat kerawanan dan kerentanan terhadap bencana yang ada maka kebijakan untuk pengurangan resiko bencana menjadi salah satu hal yang penting guna meminimalisir kerugian harta benda dan korban jiwa. Diperlukan koordinasi antarpihak dalam kegiatan pengurangan risiko bencana sangat penting dilaksanakan. Hal ini dikarenakan bencana secara langsung akan berdampak pada gangguan kehidupan dan penghidupan masyarakat, juga menghambat proses pembangunan berkelanjutan (Taslim \& Akbar, 2019).

Berdasarkan data yang dikeluarkan oleh BNPB (2011) Provinsi Sumatera Barat menempati posisi ke-6 dalam daftar kerawanan bencana. Hal ini dikarenakan kondisi geografis dari beberapa kabupaten dan Kota yang berada di wilayah pesisir yang berbatasan langsung dengan Samudara Hindia. Dengan Keadaaan geografis seperti itu maka mengakibatkan 7 kabupaten/kota dari 19 Kabupaten/Kota yang ada mempunyai tingkat kerawanan dan kerentanan yang besar terkena ancaman gempa dan tsunami. Adapun wilayah yang dimaksud adalah Kabupaten Padang Pariaman, Kabupaten Pasaman, Kabupaten Kepulauan Mentawai, Kabupaten Pesisir selatan, Kabupaten Pasaman Barat, Kota Pariaman, dan Kota Padang (Putera, Nurasa, \& Sugandi, 2016)

Berkaitan dengan data di atas maka dapat dilihat Kota Padang merupakan salah satu daerah yang rawan dan rentan terhadap gempa bumi dan tsunami. Pada Tahun 2013, dari data yang dikeluarkan oleh BNPB tentang Indeks Rawan Bencana, Kota Padang termasuk dalam kategori tinggi dan rawan terhadap bencana, dalam data disebutkan berada pada peringkat 10 secara nasional dan peringkat pertama diantara kabupaten/kota yang ada di Sumatera Barat (BNPB, 2013). 
Dengan posisi dan kondisi Kota Padang yang berada pada jalur the pasific ring of fire dan berada pada zona subduksi antara lempeng Indo-Australia dan lempeng Eurasia menjadikan Kota Padang sebagai salah satu daerah yang sering mengalami bencana gempabumi. Salah satu kejadian gempa bumi yang melanda Kota Padang adalah Gempa besar tanggal 30 September 2009, yang menimbulkan banyaknya korban harta benda dan jiwa. Seperti yang diketahui, bencana gempa bumi yang melanda Sumatera Barat termasuk Kota Padang yang mengakibatkan ribuan jiwa menjadi korban dan ribuan rumah dan fasilitas umum serta infrastuktur menjadi hancur. Data menunjukkan korban meninggal di Kota Padang adalah 316 orang, jumlah korban yang hilang 4 orang, 181 orang luka berat, 425 luka ringan

Dengan demikian, peruntukan terhadap tata ruang wilayah yang berbasis terhadap mitigasi bencana menjadi penting hal ini didasarkan bahwa Kota Padang merupakan salah satu daerah yang memiliki tingkat kerentanan dan kerawanan yang tinggi terhadap bencana alam berupa gempa bumi. Berdasarkan kondisi tersebut diperlukan adanya peruntukan tata ruang Kota Padang yang berbasis mitigasi terhadap bencana. Selain itu program ini juga sejalan dengan prioritas pembangunan Kota Padang tahun 2014-2019 yaitu pada poin 9, yang menyebutkan bahwa penataan lingkungan perkotaan yang hijau, berkelanjutan dan berbasis mitigasi bencana. ini berarti arah penataan ruang Kota Padang kedepan berorientasi kepada mitigasi bencana.

Lona P. Victoria mengemukakan bahwa mitigasi bencana dan pengurangan resiko bencana juga menawarkan kesempatan besar untuk bisa diintegrasikan manajemen bencana kedalam proses perencanaan pembangunan (Victoria, (BPBD, 2009).

2016). Dengan demikian nantinya, persoalan kebencanaan merupakan suatu hal yang penting dalam pembangunan. Misalnya Kota Padang, sebelum terjadinya Gempa Aceh tahun 2004, Kota Padang merupakan Kota dengan kawasan pantai yang menarik untuk dikembangkan, sehingga dalam rencana strategis Kota Padang, Kota Padang diprioritaskan menjadi sebuah kota dengan julukan Water From City, yang termuat dalam RTRW Kota Padang Tahun 2008-2028, dimana Kota Padang mempunyai Kota Kembar yang hampir mirip dengan Kota Padang yaitu di Negara Vietnam yaitu Kota Vũng Tàu sebuah kota di Provinsi Bà Rịa-Vũng Tàu dan Kota Hildesheim, sebuah Kota di Lower Saxony di Jerman.

Namun setelah terjadinya Gempa Padang Tahun 2009, rencana pembangunan menjadi berubah, dimana perubahan tersebut tertuang dalam revisi RTRW Kota Padang yang dilakukan pada Tahun 2010. Perubahan yang terjadi pada RTRW mulai mempertimbangkan aspek kebencanaan dalam perencanaan daerah. RTRW dibuat dengan tujuan adalah Kota Padang yang metropolitan yang berbasis mitigasi bencana. Dengan demikian kebencanaan merupakan hal sangat penting, mengingat Kota Padang yang rawan bencana, sehingga tidak memungkinkan untuk melakukan pembangunan di daerah-daerah yang rawan bencana. Langkah selanjutnya yang dilakukan dalam rangka memasukkan manajemen bencana ke dalam proses pembangunan adalah dengan adanya pembuatan zonasi-zonasi gempa, dimaan diberi tanda dengan warna merah, kuning dan hijau.

Pada awal peneliti menelaah beberapa penelitian yang relevan dengan penelitian ini dan menjadikan penelitian ini berbeda dengan penelitian yang sudah ada. Penelitian Bevaola Kusumasari dkk Copyright @ 2020, Publik (Jurnal Ilmu Administrasi), ISSN: 2301-573X (Print), ISSN: 2581-2084 (Online) 
((Kusumasari, Alam, \& Siddiqui, 2010)) tentang Resource Capability For Local Government In Managing Disaster menghasilkan bahwa kapabilitas pemerintah daerah dalam menghadapi bencana dilihat dari dimensi kelembagaan, sumber daya manusia, keuangan, teknis, implementasi kebijakan yang tepat dan kepemimpinan. Penelitian dilakukan di Kabupaten Bantul yang hasilnya adalah bahwa kapabilitas kelembagaan yang dimiliki oleh Kabupaten Bantul dalam menghadapi bencana sangatlah terbatas, namun untuk kapabilitas sumber daya manusia relatif memadai, dari segi kebijakan belum ada kebijakan tentang penanggulangan bencana pada saat terjadi gempa tahun 2006, dari segi keuangan terbatas karena $80 \%$ dari APBD Kabupaten Bantul dialokasikan untuk belanja Rutin, sedangkan dari segi manajemen logistic (teknis) Kabupaten Bantul Mampu mengelola dengan baik dan untuk kepemimpinan, Kabupaten Bantul menunjukkan sikap yang responsif dengan memberikan bantuan yang memadai bagi korban.

Sementara itu penelitian Herry Yogaswara dkk (2012) tentang Kajian Kebijakan Pengurangan Resiko Bencana yang Berbasis Kearifan Lokal: Pembelajaran Peraturan daerah No. 8 Tahun 2010 di Provinsi Daerah Istimewa Yogyakarta menghasilkan penelitian bahwa dalam peraturan daerah perlu juga diperhatikan indigenous knowledge (pengetahuan masyarakat asli), dalam masyarakat jawa di kenal filosofi sepi ing pamrih rame ing gawe. Hubungan harmonis antara manusia dengan sesame manusia, manusia dengan sang pencipta, manusia dengan alam dan mahluk lainnya melalui filosofi Hamemayu Hayuning Bawono. Kemudian Filsosofi dimana manusia wajib mengasah ketajaman budi dan membersihkan keburukan yang ada di atas bumi (mangasah mingising budi, masuh malaning bumi. Selain itu konsepkonsep seperti lantip (menjadi tajam) maupun guyup rukun, semakin memberikan penajaman tentang pentingnya kearifan loka dalam penanggulangan bencana.

Penelitian lainnya adalah yang dilakukan oleh Yustiningrum, (2012) dengan judul Dinamika Kebijakan Penanggulangan Bencana Tsunami di Kepulauan Mentawai. Bencana Tsunami yang melanda Mentawai ditangani dengan tanggap darurat dan rehabilitasi dan rekonstruksi. Dalam hal rehabilitasi persoalan timbul karena tempat pengungsian korban Tsunami masyakat harus memenuhi kebutuhan sendiri dengan bekerja di kebun mereka, padahal dengan adanya bencana maka banyak lahan yang rusak. Pemerintah Propinsi dan Kabupaten berusaha untuk secepatnya merelokasi korban, namun karena terkendala masalah teknis dan politis dikarenakan otoritas lokasi relokasi bukan hanya wewenang Pemerintah Kabupaten Kepulauan Mentawai tetapi juga Kementrian Kehutanan untuk alih fungsi hutan, maka relokasi korban makin lama dan korban makin tidak terlindungi secara politik.

$$
\text { Sedangkan Ruswandi }
$$
melakukan penelitian dengan Judul Model Kebijakan Pengembangan Wilayah Pesisir Yang Berkelanjutan Dan Berperspektif Mitigasi Bencana Alam Di Pesisir Indramayu Dan Ciamis menghasilkan temuan bahwa identifikasi potensi bencana alam di wilayah pesisir dengan metode interpretative structural modeling (ISM), telah menentukan bahwa yang dominan di Kabupaten Indramayu adalah gelombang badai pasang dikuti oleh abrasi dan banjir, di Kabupaten Ciamis yang dominan adalah gempa bumi, tsunami dan gelombang 
badai pasang diikuti oleh abrasi dan banjir. Identifikasi bentuk mitigasi bencana dengan ISM dan kesesuainya dengan metode perbandingan eksponensial (MPE) telah menentukan bahwa di Kabupaten Indramayu bentuk mitigasi yang dapat dibangun adalah gabungan pemecah ombak, peredam abrasi dan penahan sedimentasi sejajar pantai diikuti oleh gabungan remangrovisasi, terumbu karang buatan dan revitalisasi gisik/pantai. Di Kabuapaten Ciamis adalah sistem peringatan dini diikuti oleh penyelamatan diri. Kebijakan pengembangan wilayah pesisir hendaknya sudah memperhitungkan anggaran yang proporsional untuk mewujudkan pembangunan sistem perlindungan pesisir terpadu. Upaya yang dilakukan lebih bersifat pro aktif, yang menekankan kepada upaya pencegahan dan kesiapsiagaan. Hal ini sesuai kesepakatan global untuk merubah paradigma lama yang responsif, reaktif, dan kedaruratan. Analisis dengan (analytical hierarchy process) AHP telah menentukan alternatif kebijakan untuk diterapkan di Kabupaten Indramayu yaitu mengembangkan prasarana dan sarana wilayah pesisir berperspektif mitigasi bencana. Di Kabupaten Ciamis, meningkatkan partisipasi stakeholder untuk menghindari peran dominan yang berlebihan dari satu pihak pada pihak lain. Sintesis dari berbagai kebijakan tersebut menghasilkan suatu model kebijakan yaitu mengembangkan prasarana dan sarana wilayah pesisir berperspektif mitigasi bencana serta meningkatkan partisipasi stakeholder.

Sementara itu Akmad Jufriadi dkk (2012) melakukan penelitian dengan judul Sosialisasi "Pengurangan Resiko Bencana" Di Kecamatan Tempursari Kabupaten Lumajang Sebagai Upaya Pendidikan Mitigasi Bencana. Hasil penelitian menyimpulkan bahwa 1) Pemahaman Copyright $\odot$ 2020, Publik (Jurnal Ilmu Administrasi), ISSN: 2301-573X (Print), ISSN: 2581-2084 (Online) masyarakat tentang kebencanaan relatif cukup baik dinilai dari aspek sensitivitas dalam merespon bencana, cara merefleksi bencana, kesadaran untuk mengurangi bencana dan tindakan menghindari yang dilakukan saat terjadi bencana. 2) Pemahaman tentang pendidikan mitigasi bencana relatif sudah ada. 3) Pendekatan pengetahuan kebencanaan merupakan modal penting bagi pendidikan mitigasi bencana relatif sudah dimiliki oleh masyarakat. 4) Pelaksanaan sosialisasi pengurangan resiko bencana dinilai baik sebagai upaya pendidikan mitigasi bencana.

Penelitian ini menjadi menarik dikarenakan bahwa kondisi Kota Padang yang rawan dan rentan terhadap ancaman bencana alam khususnya gempa bumi, memerlukan pola ruang dan peruntukan ruang yang aman terhadap bencana. Rencana tata ruang wilayah yang telah ada belum mampu mengakomodasi kebutuhan terhadap ruang itu sendiri, karena masih didapatkan ruang-ruang wilayah di Kota Padang yang belum ramah terhadap bencana. Untuk itu dalam penelitian ini dapat dijelaskan bahwa perlu adanya kebijakan yang tegas dari Pemerintah Kota Padang terhadap peruntukan ruang dimasa yang akan datang sehingga masyarakat yang akan memanfaatkan ruang menjadi faham dan mengerti tentang kondisi wilayah yang akan dimanfaatkan.

Michael Hill dan Peter Hupe (2002) mengembangkan diskusi meta teori yang komprehensif tentang teori-teori implementasi. Pada dasarnya, tidak terdapat proses kompetisi ataupun kontestasi di antara model implementasi kebijakan karena isu yang relevan adalah kesesuaian implementasi dengan kebijakannya itu sendiri. Sehingga perlu dicatat menurut Nugroho (2017) bahwa setelah mengetahui model-model kebijakan, masalah penting adalah bahwa 
tidak ada model terbaik dalam setiap implementasi kebijakan. Setiap jenis kebijakan publik memerlukan model implementasi kebijakan yang berlainan. Ada kebijakan publik yang perlu diimplementasikan secara top down ada juga kebijakan publik yang perlu diimplementasikan secara bottom-up.

Jadi, memang tidak ada pilihan model yang terbaik, yang dimiliki adalah pilihan-pilihan model yang harus dipilih secara bijaksana sesuai dengan kebutuhan kebijakannya sendiri. Namun, satu hal yang paling penting adalah yakni implementasi kebijakan haruslah menampilkan keefektifan dari kebijakan itu sendiri. Untuk itu, dari berbagai teori implementasi kebijakan yang dipaparkan L.N. Gerston (2008) yang mensyaratkan adanya empat dimensi yang dapat dimanifestasikan terhadap keberhasilan dan kegagalan implementasi kebijakan, sehingga teori ini merupakan teori yang relevan dan lebih sesuai untuk menganalisis implementasi kebijakan penataan ruang berbasis mitigasi bencana di Kota Padang.

\section{METODE PENELITIAN}

Metode penelitian menggunakan kualitatif dengan pendekatan deskriptif interpretatif (Denzim K N and Y S, 2005), pilihan terhadap pendekatan kualitatif ini di dasarkan pada rumusan dan tujuan yang hendak dicapai dalam penelitian ini (Neuman, 2014). Lokasi Penelitian adalah Kota Padang dan Kota Pariaman, Propinsi Sumatera Barat. Dipilihnya Kota Padang, dikarenakan Kota Padang merupakan salah satu daerah yang memiliki kerentenana dan kerawanan yang tinggi terhadap bencana alam. Unit Analisis adalah kepada lembaga-lembaga yang terkait dengan Implementasi Kebijakan Penataan Ruang Berbasis Mitigasi Bencana di Kota Padang.
Sedangkan Jenis dan Sumber data berupa data primer dan sekunder. Pemilihan informan penelitian dilakukan dengan cara purposive berdasarkan kedudukan mereka dalam lembaga yang terlibat dalam implementasi kebijakan penanggulangan bencana. Dengan demikian jumlah informan pada akhirnya sangat ditentukan oleh orang-orang yang akan dijadikan informan. Teknik Pengumpulan Data dilakukan dengan cara teknik observasi, wawancara bebas (interview) yang akan dilakukan didasarkan pada pedoman wawancara yang berisikan pertanyaan terbuka (open ended question), serta telaah dokumen dan studi kepustakaan. Analisis Data dilakukan dengan dengan analisis deskriptif kualitatif. Data-data sudah dianalisis tersebut disusun dalam satuansatuan yang dikategorikan untuk lebih mudah di coding serta mengadakan pemeriksaan keabsahan data yang selanjutnya dilengkapi dengan data analisis statistik deskriptif guna penulisan laporan (Miles and Huberman, 2014).

\section{HASIL DAN PEMBAHASAN}

Penataan tata ruang yang berbasis mitigasi bencana merupakan suatu hal yang penting untuk dilakukan terutama bagi daerah yang rawan bencana. Berbagai bencana alam yang terjadi telah membukakan mata semua pihak betapa pentingnya usaha dalam penanggulangan bencana. Peruntukan terhadap tata ruang wilayah yang aman terhadap bencana menjadi penting mengingat Kota Padang merupakan salah satu daerah yang tinggi rawan gempa bumi.

Sebelum kejadian Gempa Aceh Tahun 2004, maka peruntukan tata ruang wilayah Kota Padang diarahkan ke Timur Kota Padang, yaitu dengan membangun Kawasan Pantai Padang atau diistilahkan dengan Padang water from city. Namun 


\section{Available Online at http://journal.umgo.ac.id/index.php/Publik \\ Publik (Jurnal Ilmu Administrasi) Vol 9 (2), Desember 2020}

setelah terjadinya gempa di Padang tahun 2007 yang berpusat di Solok dan Kota Padang salah satu daerah yang terpapar, maka perubahan peruntukan pembangunan berubah arah, ditambah juga dengan adanya penelitian dari LIPI dan NTU Singapura yang menyatakan Kota Padang rawan terhadap gempa dan Tsunami yang diakibatkan oleh Mega Trust Mentawai yang kekuatan gempanya diprediksi sampai 8,8 SR. Dengan adanya beberapa kejadian tersebut maka dilakukan lah revisi terhadap RTRW Kota Padang tahun 20082028. Perkembangnnya adalah Pemerintah Kota Padang Tahun 2010 sudah melakukan penyusunan RTRW Kota Padang. RTRW disusun dalam jangka waktu 20 tahun, namun satu kali dalam lima tahun bisa dilakukan revisi. Penyusunan RTRW pada tahun 2010 ini merupakan salah satu langkah dalam mitigasi bencana, dimana merupakan perbaikan terhadap RTRW tahun 2008-2028, yang mana pada RTRW sebelumnya itu belum pertimbangkan mitigasi bencana. Perubahan RTRW tersebut tertuang dalam perubahan RTRW 2010-2030 yang telah ditetapkan dalam Perda No. 4 tahun 2012. Perda tersebut menjadi acuan bagi Pemko Padang dan masyarakat umum dalam perencanaan, pemanfaatan dan pengendalian pembangunan di Kota Padang. Salah satu revisi yang cukup signifikan adalah memperhitungkan daerah-daerah yang rawan terhadap bencana gempa bumi dan tsunami. Maka dalam perbaikannya di jelaskan bahwa membatasi pengembangan hunian di kawasan sepanjang pantai yang rawan terhadap bencana tsunami (pasal 14). Selain itu juga ada strategi-strategi yang perlu dilakukan pemerintah yaitu dengan membuat rencana-rencana ruang evakuasi, tempat evakuasi, jalur evakuasi dengan berkoordinasi dengan SKPD terkait dalam hal ini Dinas Pekerjaan Umum dan Penataan Ruang (PUPR). Di buatnya Copyright (C) 2020, Publik (Jurnal Ilmu Admini (Online) zonasi gempa berupa zona merah, zoan kuning dan Zona hijau, dalam pembuatan zonasi ini adanya koordinasi antara SKPD terkait dengan BPBD, pada awal penentuan zonasi tahun 2010 zona merah tsunami tidak mempertimbangkan kepadatan bangunan, sehingga zona merah jauh sampai ke Jalan By Pass, namun ada revisi pada tahun 2013 mulai memperhitungkan kepadatan bangunan sehingga untuk penentuan zonasi ini ditetapkan oleh BPBD dengan berkonsultasi dengan Disaster Risk Reduction (Kogami) .

Dalam peruntukan tata ruang tersebut pemerintah daerah sudah menentukan kawasan rawan bencana namun belum sempurna karena masih ada kawasankawasan rawan bencana yang masih gunakan masyarakat untuk perumahan seperti Tabiang Banda Gadang, Parupuk Tabiang, yang mana daerah tersebut berada pada di pinggir pantai yang rawan terhadap gemap bumi dan tsunami. Pada tahun 2015 dilakukan lagi peninjauan terhadap RTRW Kota Padang dimana dalam salah satu kajiannya memasukkan kajian terhadap resiko bencana, dalam hal ini kajian resiko bencana dilakukan oleh BPBD, yaitu berupa kajian resiko bencana gempa bumi.

Persoalan tata ruang yang berbasis mitigasi bencana di Kota Padang masuk dalam prioritas pembangunan Kota Padang Tahun 2014-2019 yaitu Pentaan lingkungan perkotaan yang hijau, berkelanjutan dan berbasis mitigasi bencana. Dengan tertuang dalam Tujuan RTRW Kota Padang yaitu kota padang yang metripolitan yang berbasis mitigasi bencana. Sehingga dengan demikian pemerintah dalam hal ini melalaui dinas terkait akan melakukan berbagai program/kegiatan untuk mendukung hal tersebut, salah satunya adalah adanya kerjasama dengan pihak swasta, pemilik gedung-gedung bertingkat seperti hotel, , ISSN: 2301-573X (Print), ISSN: 2581-2084 
dan adanya pembuatan tsunami save zone, yaitu berupa tanda atau rambu yang di pasang pada jalan raya yang merupakan tanda bahwa daerah tersebut sudah berada pada titik aman gelombang tsunami. Program ini sudah berjalan awal tahun 2017 ini dan sudah bisa dilihat beberapa ruas jalan di Kota Padang yang sudah di pasang tsunami save zone. Dengan adanya pemasangan atau penanda ini diharapkan masyarakat mengerti dan faham bahwa tempat mereka berada sudah aman atau belum terhadap ancaman tsunami.

Selain itu terkait dengan infrastruktur maka perlulah penataan ruang yang berbasis ancaman, yang perlu dilakukan adalah pertama dengan menggeser manusianya, digeser menjauhi ancaman, bisa dengan melakukan penggeseran pemukiman, atau dibuatkan ke arah vertikal, bertingkat dan atau berada di atas elevasi, karena di Padang tidak ada kebijakan relokasi, hal ini disebabkan biaya dan tempat relokasi yang memang tidak ada, sehingga memang perlu mengedukasi masyarakat supaya mereka tanggap terhadap bencana dan mau berpindah atau membuat bangunan yang lebih tinggi dan tahan terhadap bencana. Penataan ruang di Kota Padang perlu disiasati karena salah satu aspek resiko yang ditimbulkan oleh bencana adalah bidang ekonomi, masyarakat ekonomi lemah lebih rentan dibandingkan dengan yang kuat, karena terkait dengan keterbatasn akses dan modal. Sehingga pemerintah Kota Padang sudah mulai mengembangkan beberapa daerah di pingggir Pantai Padang yang merupakan salah satu dari strategi mitigasi bencana.

Disisi lain persoalan penataan ruang juga masih menjadi masalah, yaitu berupa tata ruang yang kebijakannya masih tidak mengadopsi ancaman, misalnya di wilayah Air Pacah merupakan zona merah untuk amplifikasi gempa, sudah ada peta ancaman gempanya, zonasi gempanya paling tinggi amplifikasinya, kalau terjadi gempa di Padang maka daerah yang paling parah terkena adalah air pacah karena disana akan dirasakan lebih besar getarannya, contoh kejadian gempa Solok tahun 2007 saja, Kota Padang termasuk daerah yang terpapar, di kawasan Air Pacah tepatnya di daerah Simpang Maransi, ada rumah tiga lantai hancur dan yang lainnya pada miring, padahal Solok sendiri pada waktu itu tidak terlalu parah, dan sementara itu di beberapa wilayah di Padang juga tidak mengalami kerusakan yang parah.

\section{Pengaturan Pembangunan, Pengaturan Infrastuktur Dan Tata Bangunan}

Bagi daerah yang memiliki tingkat kerentanan dan kerawanan yang tinggi terhadap ancaman gempa bumi seperti Kota Padang, tentunya perlu memperhatikan aspek pengaturan pembangunan fisik, pengaturan infrastruktur dan penataan bangunan. Berdasarkan kepada kejadian gempa Padang tahun 2009, yang menyebabkan banyaknya korban jiwa dan kerusakan bangunan, maka saat ini Kota Padang telah menetapkan Peraturan Daerah No. 7 Tahun 2015 tentang bangunan gedung. Dimana dalam peraturan tersebut diatur bagaimana suatu bangunan itu dibuat dan dibangun dari segi konstruksi bangunannya dan ketahanannya terhadap getaran atau gempa. Peraturan tersebut dibuat untuk mempersiapkan seluruh bangunan yang ada di Kota Padang memenuhi standar, sehingga Pemerintah Kota Padang dalam hal ini Dinas Tata Ruang dan Tata Bangunan telah memberikan perhatian yang serius terhadap pembangunanpembangunan yang dilakukan di Kota Padang, khususnya bangunan bertingkat, 
misalnya Ruko, Hotel, Sekolah dan lainlain, hal ini dikarenakan dengan adanya pembangunan tersebut diharapkan nantinya akan dapat memberikan manfaat ganda yaitu bisa sebagai bangunan shelter.

Dalam hal penyusunan peraturan daerah, Pemerintah Kota Padang yang dalam hal ini yang ikut terlibat dengan penyusunan perda bangunan gedung adalah Dinas TRTB (sekarang Dinas PUPR) dengan melibatkan BPBD, Bappeda dengan SKPD lain dengan melakukan koordinasi berupa rapat dengan bidang terkait dalam sekali sebulan. Dalam peraturan tersebut Kualitas bangunan gedung menjadi perhatian hal ini bisa diambil contoh dari kejadian gempa Solok yang berkekuatan 6,7 SR menelan Korban jiwa sebanyak 60 orang, sementara itu Gempa Jogjakarta 2006 dengan kekuatan gempa 6,4 SR menelan korban jauh lebih banyak yaitu 6000 orang, ini menandakan kualitas bangunan di Jogjakarta jauh lebih rendah dibandingkan dengan Solok dan sekitarnya, sehingga yang perlu diperhatikan adalah bangunannya, bukan gempanya. Sehingga faktor bangunan yang kurang berkualitas juga bisa menentukan banyak sedikitnya jumlah korban jiwa. Berdasarkan pengalaman tersebut maka Kota Padang menerbitkan Peraturan Daerah No. 7 Tahun 2015.

Terkait dengan bangunan fisik gedung sesuai dengan ketentuan Peraturan Daerah No. 7 tahun 2015. Dalam peraturan tersebut disebutkan ada persyaratan pembangunan gedung yang aman terhadap bencana, misalnya kalau gedung pelayan publik apa syaratnya. Setiap bangunan layanan publik itu harus disidangkan di depan Tim ahli bangun gedung, Tim ahli hadir dan pemilik hadir untuk penetapan izin bangunan yang juga di hadiri dari Dinas PUPR, BPBD, Bappedalda dan pihak terkait lainnya. Bangunan gedung mulai dari perencanaan, pendirian dan Copyright @ 2020, Publik (Jurnal Ilmu Administrasi), ISSN: 2301-573X (Print), ISSN: 2581-2084 (Online) sampai berfungsi harus mendapat izin bangunan dari Dinas PUPR.

Sebenarnya mengenai pembangunan gedung yang ramah terhadap gempa sebenarnya sudah lama dilakukan advokasi oleh beberapa NGO yang ada di Padang seperti Mercy Corps, yang merupakan LSM internasional dari Amerika. Mercy Corps bekerjasama dengan BPBD, Dinas PU, dan Dinas TRTB (sekarang Dinas PUPR telah melaksankan program terkait dengan pembangunan bangunan ramah gempa. Program ini juga melakukan advokasi kepada para pengelola gedung yang sudah di banguan supaya gedung tersebut bisa di Uji oleh Dinas PUPR, apakah sudah ramah dan aman gempa sehingga nantinya bisa dijadikan sebagai shelter. Namun yang terjadi dengan program ini adalah menjadi terputus, karena Mercy Corps sudah berakhir kegiatannya di Bidang ini, sehingga perlu niat baik dari pemerintah Kota untuk melanjutkan, namun yang peneliti temui di lapangan, kegiatan ini terhenti sering dengan terhentinya program dari Mercy Corps tersebut.

Selain itu kajian resiko bencana juga telah dilakukan oleh BPBD dan dinas terkait guna melihat kemungkinan resiko bencana yang akan dihadapi Kota Padang dalam melakukan pembangunan, namun karena kurangnya koordinasi antar oragnisasi di daerah dan mengakibatkan pada akhirnya program pembangunan menjadi tidak sinkron, mitigasi menjadi tidak terlaksana dengan baik, dokumen ancaman resiko bencana yang sudah dibuat sebelumnya tidak masuk dalam perencanaan dan kebijakan yang ada, sehingga berdirilah bangunan-bangunan yang tidak memperhatikan kajian yang sudah dilakukan. 
Perubahan tata ruang pembangunan wilayah hendaknya juga dijalankan secara perencanaan teknis dan juga pelan-pelan, karena selain aspek teknis tersebut ada juga aspek psikologis, bagaimana cara membuat masyarakat pindah dari daerah yang sudah lama mereka tempati, ada caracara persuasif yang perlu dilakukan bukan hanya dengan cara penggusuran yang seperti banyak dilakukan kota-kota besar di Indonesia. Misalnya Jakarta. Selain itu juga harus diperhatikan juga bagaimana merubah dan membangun persepsi masyarakat untuk bisa memperbaiki kualitas bangunan, karena selama ini yang terjadi di Kota Padang, banyak bangunan yang dibangun asal jadi saja tanpa memperhitungkan kualitas dari bangunan tersebut, terutama perumahan rakyat, karena menjadi dilema juga bagi masyarakat, karena untuk membangun rumah yang aman terhadap gempa itu memerlukan dana yang sedikit lebih banyak dari pada membangun rumah yang biasa saja, karena ada beberapa spek dan komponen yang perlu ditambahkan supaya bangunan tersebut menjadi kuat dan tahan terhadap goncangan. Namun semenjak gempa tahun 2009, di beberapa tempat pembangunan gedung-gedung pemerintah dan swasta, sudah memperhatikan ancaman terhadap gempa, misalnya untuk keperluan bisnis, sudah ada hotel-hotel yang dibangun dengan memperhatikan kondisi ini, sehingga apabila hotel atau atau Convention Hall tersebut tidak aman terhadap gempa, maka masyarakat tidak akan bersedia untuk memanfaatkannya, begitu juga dengan bangunan rumah, jika rumah tidak aman dan ramah terhadap gempa maka masyarakat tidak akan mau bertamu ke rumah tersebut. Selain itu, perhatian terhadap hal ini, bukan saja hanya pada bangunan, namun juga pada orang yang ada dalam bangunan tersebut.
Selain itu Pemerintah Kota Padang juga merencanakan pembangunan bukit Buatan seperti TEP (tsunami evacution park) dan penyiapan emergency landing, kenapa itu perlu diadakan?, dengan asusmi jika terjadi gempa (belajar dari kasus gempa Aceh, 2004), seluruh fasilitas publik yang dekat dengan pantai seperti Bandara Internasional Minangkabau dan Bandara Tabing, serta pelabuhan Teluk Bayur dan Bungus Teluk Kabung akan hancur. Fungsi dari emergency landing adalah untuk mengirimkan logistik lewat udara serta bantuan kepada masyarakat. Untuk emergency landing itu rencanakan di bangun di Jalan Padang by pass yang segmennya bisa antara TVRI Sumatera Barat dan Lubuk Minturun karena mempunyai track lurus sepanjang 1KM lebih, hal ini cukup untuk menjadi runway bagi pesawat yang akan mendarat. Rencana ini mendapat respon positif dari Presiden Jokowidodo untuk melaksanakan pembanguan emergency landing tersebut.

\section{Pengaturan Infrastruktur Membangun Jalur Evakuasi}

Dengan

Penyediaan prasarana dan infrastruktur, merupakan bagian dari mitigasi struktural, misalnya penyediaan jalur evakuasi. Untuk pelaksanaannya tanggung jawab diserahkan ke Dinas Pekerjaan Umum, sedangkan perencanananya ada di Dinas TRTB (sekarang Dinas PUPR). Penyediaan jalur evakuasi ini, pemerintah mencanangkan jalur-jaluar evakuasi, yang melintang dari barat ke timur, yaitu mulai dari pesisir barat menuju ke jalan by pass, karena Kota Padang memanjang dari utara ke selatan. Ada 12 ruas jalur evakuasi yang disiapkan, dan itu pekerjaannya dilakukan bekerjasama dengan Propinsi Sumatera Barat dan Balai Jalan Nasional. Dimana masing-masing instansi memiliki tugas dan 
kewenangan yang berbeda terkait dengan pembanguan jalur evakuasi tersebut. Jalur evakuasi beberapa telah dilebarkan dan ditingkatakan kualitasnya. Baik jalur yang besar seperti Alai-By Pass, jalan-jalan yang kecil seperti jalan Inspkesi di jalan Banda Bakali. Sementara itu jalan-jalan yang di kompleks perumahan juga diupayakan ditingkatkan kualitasnya dan dilebarkan sebagai jalur evakuasi. Program ini juga didukung oleh pihak dunia Internasional, dengan pembangunan salah satu jalur jalur evakuasi di daerah Pasir Nan Tigo Kota Padang, pembangunan jalur ini dilakukan dalam rangka kegiatan / program Pasific Partneship yang dikerjakan oleh tentara Amerika dengan membangun jalan sepanajang $1 \mathrm{KM}$. Selain itu juga merencanakan pelebaran beberapa unit jalan di daerah Kota Tangah dan kuranji. Untuk pembangunan jalan tersebut dianggarkan dalam APBD. Namun tidak semua jalur bisa dibangun dengan baik, kondisi dilapangan menjadi kendala, diantaranya mengenai kepemilikan lahan. Kepemilikan lahan di Kota Padang dimiliki oleh kaum atau suku atau disebut juga tanah ulayat, yang mana kepemilikannya menyangkut banyak orang, sehingga ada kesulitan bagi pemerintah untuk melakukan pembebasan tanah.

\section{Penataan Bangunan dengan pembangunan Shelter}

Pembangunan shelter evakuasi ini merupakan bagian dari mitigasi struktural yang dilakukan oleh pemerintah Kota Padang. Shelter yang dibangun merupakan bentuk daripada proses evakuasi vertikal yang dilakukan jika gempa yang terjadi menimbulkan tsunami. Shelter-shelter yang ada merupakan bangunan pemerintah yang bisa dipakai oleh masyarakat, selain itu juga bangunan milik perorangan, atau swasta yang bisa dimanfaatkan untuk evakuasi. Dalam hal ini pemerintah telah melakukan koordinasi dengan pihak-pihak terkait terutama yang dari swasta atau perorangan bahwa bangunan milik mereka suatu saat jika terjadi bencana bisa dipakai oleh masyarakat menjadi shelter.

Strategi yang dilakukan oleh Pemerintah Kota Padang dalam penyedian shelter adalah dengan menjadikan sekolah, perkantoran, pasar, rumah ibadah dan seluruh bangunan bertingkat seperti hotelhotel bisa dapat dipakai untuk shelter. Dengan adanya strategi tersebut maka pemerintah dapat menghemat biaya dalam penyediaan shelter. Karena menurut data dilapangan untuk membangun satu shelter itu membutuhkan dana sampai 20 Milyar. sehingga dengan adanya pemanfatan gedung-gedung tersebut biaya yang dikeluarkan menjadi berkurang.

Sementara itu, dalam hal pemanfaatan gedung milik sawasta sebgai shelter maka Pemerintah Kota Padang perlu membuat MoU dengan pihak terkait, karena pemerintah perlu menjelaskan kepada pemilik gedung, bahwa apabila terjadi bencana maka gedung tersebut bisa di pakai oleh masyarakat untuk menyelamatkan diri. Salah satu pihak swasta yang menyambut baik program ini adalah Hotel Grand Zuri. Menurut hasil wawancara dengan informan BPBD dan Mercy Corps Hotel Grand Zuri adalah satu-satunya hotel di Kota Padang yang telah menanda tangani kerjasama (MoU) dengan pemerintah kota, pihak hotel bersedia menampung masyarakat yang ingin menyelamatkan diri dari ancaman gempa yang disertai tsunami, di hotel ini juga sudah tersedia gudang untuk camp pengungsian sementara dan juga telah dipasangi sirine tsunami.

Selain itu beberapa shelter dari sejumlah gedung di Kota Padang yang sudah di peruntukkan seperti SMA 1 Padang, SMK 5 Padang, SMP 25 Padang, SMP 7 Padang, escape building di Kantor Copyright @ 2020, Publik (Jurnal Ilmu Administrasi), ISSN: 2301-573X (Print), ISSN: 2581-2084 (Online) 
Gubernur Sumater Barat, Gedung Kepolian Daerah Sumatera Barat, Pasar Raya, Dan juga beberapa gedung yanga ada di kampus Universitas Negri Padang. Namun hasil penelitian di lapangan menunjukkan bahwa ada beberapa shelter yang dibangun oleh Pemerintah dalam hal ini BNPB Pengelolaan shleternya tidak jelas, karena sampai sekarang ini ada dua shelter yang belum diserah terimakan dari pemerintah pusat kepada pemeintah daerah (BPBD). Sehingga pemanfaatan terhadap shelter tersebut menjadi sulit, dikarenakan akses ke shelter menjadi terkendala.

\section{PENUTUP}

\section{Kesimpulan}

Adapun dari hasil penelitian yang telah dilakukan dan dipaparkan sebelumnya secara umum dapat dikatakan bahwa implementasi kebijakan penataan ruang yang berbasis pada mitigasi bencana masih menghadapi persoalan yang terkait dengan praktiknya di lapangan, implementasi kebijakan belum berjalan sesuai dengan apa yang dinginkan, masih terdapat kelemahan-kelemahan yang berasal dari penyelenggara kebijakan maupun masyarakat. Sehingga kedepan diperlukan kajian lebih lanjut tentang implementasi kebijakan penataan ruang yang berkaitan dengan bencana gempa bumi. Mengingat kajian tentang kebencanaan masih belum banyak dikaji dalam konteks administrasi publik

\section{Saran}

Perlu adanya peningkatan kapasitas masyarakat dan lembaga terkait dengan penyelenggara penanggulangan bencana di daerah, mengingat intensitas bencana yang yang terjadi di Kota Padang. Sementara itu BPBD sebagai leading sector dalam penyelenggaraan penanggulangan bencana di daerah diharapkan dapat menjalankan fungsinya sebagai komando, koordinator dan bukan hanya sebagai fungsi pelaksana saja. Sedangkan sosialisasi mengenai pengurangan resiko bencana kepada masyarakat perlu di tingkatkan dan diperbaiki, baik dari segi materi sosialisasinya maupun instruktur yang melakukan sosialisasi, sehingga sosialisasi dapat berjalan lebih efektif. Cara lain yang dilakukan adalah revisi terhadap RTRW Kota Padang mesti segera dituntaskan mengingat masih adanya masyarakat yang membangun di daerah yang rawan bencana dan Pemerintah Kota Padang memperketat izin mendirikan bangunan terutama di daerah yang rawan bencana

\section{DAFTAR PUSTAKA}

Denzim, N. K., \& Lincoln, Y. S. (2005). Handbook of Qualitative Research (3 ed.). (N. K. Denzim, \& Y. S. Lincoln, Eds.) Thousand Oaks, California: Sage Publications.

Gerston, L. (2008). Public Policymaking In a Democratic Society: A Guide Civic Engangement. New York: M.E Sharp, Inc.

Hill, M., \& Hupe, P. (2002). Implementing Public Policy. Governance in Theory and in Practice. London: Sage.

Hughes, O. E. (1994). Public Management and Administration: an Introduction. New York: Martin's Press.

Jufriadi, akhmad; Ayu, Hena Dian; Afandi, Akhmad; Rahman, M.; Raehanayati, Sandy Vikki Ariyanto, Ika Karlina Liala Nur Suciningtyas. (2012). Sosialisasi Pengurangan Resiko Bencana di Kecamatan Tempursari Kabupaten Lumajang sebagai upaya Pendidikan Mitigasi Bencana. Erudio, 1(1). 


\section{Available Online at http://journal.umgo.ac.id/index.php/Publik \\ Publik (Jurnal Ilmu Administrasi) Vol 9 (2), Desember 2020}

Kusumasari, Bevaola; Alam, Quamrul; Siddiqui, Kamal. (2010). Resource capability for local government in managing disaster. Disaster Prevention and Management, 19(4), 438-451.

Miles, Matthew B.; Huberman, A. Michael; Saldaña, Johnny. (2014). Qualitative Data Analysis: A Methods Sourcebook (3 ed.). (M. B. Miles, A. M. Huberman, \& J. Saldaña, Eds.) Thousand Oaks, CA: Sage Publications.

Neuman, W. L. (2014). Social Research Methods: Qualitative and quantitative approaches (7 ed.). London: Pearson Education Limited.

Nugroho, R. (2017). Public Policy. Jakarta: Elex Media Komputindo.

Pramusinto, A. (2009). Pembangunan dan reformasi di bidang penanggulangan bencana di era otonomi daerah. In A. Pramusinto, \& E. A. Purwanto, Reformasi Birokrasi, kepemimpinan dan pelayanan publik: kajian tentang pelaksanaan otonomi daerah di Indonesia. Yogyakarta: Gava MediaJIAN UGM-MAP UGM (Roni Ekha Putera dkk, 2016: 147)

Putera, Roni Ekha., Heru Nurasa, dan Yogi Suprayogi Sugandi (2016), Synergizing Stakeholders in Reducing Risk of Earthquake and Tsunami-Disaster in the Most Vulnerable Area, International Journal of Administrative Science \& Organization, September 2016, Volume 23, Number 3, hal 147-155

\section{Ruswandi (2009), Model Kebijakan Pengembangan Wilayah Pesisir Yang Berkelanjutan Dan Berperspektif Mitigasi Bencana Alam Di Pesisir Indramayu Dan Ciamis, Disertasi Sekolah Pascasarjana Institut Pertanian Bogor}

Shaluf. (2007). Disaster Types. Disaster Prevention and Management, 16(5), 704-717.

Taslim, I., \& Akbar, M. F. (2019). Koordinasi Publik untuk Pengurangan Risiko Bencana (PRB) Banjir pada Pelaksanaan Pembangunan Berkelanjutan Gorontalo. Jurnal Wilayah dan Lingkungan, 7(2).

Victoria, Lorna P. (2007). Community based approached to disaster mitigation. diunduh dari website: www.adpc.net/v2007/IKM/ONLINE \%20DOCUMENTS/downloads/.../C BDM.pdf on August 12, 2017.

Weissert, C. S., \& Goggin, M. L. (2002). Non-incremental Policy Changes: Lessons From Michigan's Medical Managed Care Initiative. Public Administration Review, 6(2).

Yogaswara, Herry, Laksmi Rachmawati, Fitrianita dan Ulil Amri. (2012). Kajian kebijakan Pengurangan risiko bencana yang berbasiskan kearifan lokal: Pembelajaran Perda No. 8 Tahun 2010 Provinsi Daerah Istimewa Yogyakarta, dalam Herryzal Z. Anwar, 2012, Menyingkap Tabir Fenomena Bencana Seismik di Indonesia: Perspektif Pengurangan Risiko Bencana Gempa Bumi dan Tsunami, Bandung: Andira dan LIPI

Yustiningrum, R. E. (2012). Dinamika Kebijakan Penanggulangan Bencana Tsunami di Kepulauan Mentawai. dalam H. Z. Anwar, Menyikap Tabir Fenomena Bencana Seismik di Indonesia: Perspektif Pengurangan Resiko Bencana Gempa Bumi dan Tsunami. Bandung: Andira dan LIPI. 